\title{
Influence of nitrogen application on direct seeded rice in old and new Cauvery Delta zone of Tamil Nadu, India
}

\author{
K. Sathiya Bama* \\ Department of Soil Science and Agricultural Chemistry, Tamil Nadu Rice Research Institute, \\ Aduthurai - 612101 (Tamil Nadu), India \\ K. R. Babu \\ Department of Soil Science and Agricultural Chemistry, Agricultural College and Research Institute, \\ Vazhavacchanur - 606753 (Tamil Nadu), India \\ R. Sharmila \\ Department of Nanotechnology, Tamil Nadu Agricultural University, Coimbatore - 641003 \\ (Tamil Nadu), India

\section{A. Anuradha} \\ Department of Soil Science and Agricultural Chemistry, Agricultural College and Research Institute, \\ Eachangkottai - 614902 ( Tamil Nadu), India \\ ${ }^{*}$ Corresponding author. Email: kssoilscience@gmail.com
}

\section{How to Cite}

Bama, K. S. et al. (2021). Influence of nitrogen application on direct seeded rice in old and new Cauvery Delta zone of Tamil Nadu, India. Journal of Applied and Natural Science, 13(4), 1462 - 1469. https://doi.org/10.31018/jans.v13i4.3095

\begin{abstract}
Direct seeded rice is a boon to farmers where the water release from the reservoir is delayed. Nitrogen fertiliser management is one of the strategies bto rectify the nutrient-related issue in Direct seeded rice. The present study aimed to optimize the nitrogen dose for direct-seeded rice in the new and old Cauvery delta zone of Tamil Nadu. Field experiments were conducted during kuruvai and samba seasons at Tamil Nadu Rice Research Institute, Aduthurai and Agricultural research station Thanjavur representing old and new Cauvery delta regions during 2019-20 and 2020-21. Totally from eight experiments, the results of four field experiments in each location revealed the highest grain yield in the treatment T6 -application of $150 \mathrm{~kg} \mathrm{Nha}^{-1}(5596 \mathrm{~kg} / \mathrm{ha})$ which was statistically on par with treatment T5 $-125 \mathrm{~kg} \mathrm{~N} / \mathrm{ha}(5326 \mathrm{~kg} / \mathrm{ha})$ in old delta and new delta. The higher grain yield was recorded in the T6 (5140 kg/ha), statistically on par with T5 (4550 kg/ha). The higher available nitrogen content of $312 \mathrm{~kg} / \mathrm{ha}, 292 \mathrm{~kg} / \mathrm{ha}$ was recorded for N application @ 150kg/ha, which was statistically on par with $309 \mathrm{~kg} / \mathrm{ha}$ and $289 \mathrm{~kg} / \mathrm{ha}$, respectively, both the kuruvai and samba seasons for $\mathrm{N}$ application of 125 $\mathrm{kg} / \mathrm{ha}$. In the new CDZ, the same trend was followed as that of the old delta. Based on economics, N applied @125 kg/ha recorded a higher $\mathrm{BC}$ ratio for direct-seeded rice. For the benefit of farmers of both deltaic regions, the nitrogen application of $125 \mathrm{~kg} \mathrm{ha}^{-1}$ for direct-seeded rice is recommended.
\end{abstract}

Keywords: Cauvery delta, Direct seeded rice, Nitrogen management, Yield, Nutrient uptake

\section{INTRODUCTION}

Tamil Nadu has an area of 1.8 million ha of rice cultivation with the production of 7.9 million tonnes and the average yield level is $3.9 \mathrm{t} / \mathrm{ha}$. More than 85.00 per cent of Tamil Nadu districts have a yield level of $>2.5 \mathrm{t} / \mathrm{ha}$. However, the Yield gap is around $2.1 \mathrm{t} / \mathrm{ha}$ (Vasanthakumar, 2017). Among various means of improving rice productivity, direct-seeded rice is a technology where the water release is delayed. India has a large deltaic area for crop cultivation (Gopal et al., 2019). In Tamil Nadu, the Cauvery delta is the biggest rice area and occupy a major area. Direct seeded rice occupied around thirty per cent of the Cauvery delta area. In the direct-seeded rice (DSR), the maturity is somewhat quicker than normal transplanting. In this situation, nutrient management study plays an important role in the DSR. Nitrogen $(N)$ is an essential macronutrient for the growth of rice (Oryza sativaL.) and the major factor with respect to the development of high-yielding rice cultivars. Nitrogen fertilizers have been applied with increasing amounts in rice production, which has led to a drastic increase in $\mathrm{N}$ loss or removal resulting from $\mathrm{N}$ leaching, runoff, denitrification 
and ammonia volatilization (De Datta, 1995; Zhu et al., 2000; Choudhury and Kennedy, 2005; Yoon et al., 2006; Thuy et al., 2008; Alam et al., 2021). From 2004 to2014, the average $\mathrm{N}$ recovery efficiency (NRE) and Nagronomic efficiency (NAE) of applied $\mathrm{N}$ for rice production were only $39 \%$ and $13 \mathrm{~kg} / \mathrm{kg}$, respectively (Yu et al., 2015), both of which were significantly lower than the global average Nitrogen recovery efficiency $(46 \%)$ and NAE (22 kg/kg) for rice (Ladha et al., 2005). Fertilization based on plants' nutrient requirements and uptake ability can greatly enhance $\mathrm{N}$ use efficiency (NUE) and reduce atmospheric and aquatic pollution. Additional studies on nutrient uptake at different rice growth stages found that $\mathrm{N}$ uptake is low at the seedling stage but peaks at the tillering and booting stages, with approximately $34 \%, 38 \%$ of the total $\mathrm{N}$ absorption occurring from jointing to heading ( $\mathrm{YU}$ et al., 2013). Qi et al. (2012) found that delaying the first urea application increases plant growth, grain yield significantly, aboveground $\mathrm{N}$ uptake and NRE of dry direct-seeded rice. From the perspective of reducing labour costs and increasing NRE, $N$ fertilizer was applied to direct-seeded rice as three split applications, such as basal, tillering, and panicle. Usually, basal fertilizer is broadcast and incorporated into puddled soils shortly before direct seeding, tillering fertilizer is broadcast (top dressed)at the initial tillering stage, and panicle fertilizer is top-dressed at the panicle initiation or heading stage. In direct-seeded rice, Xu et al. (2018) found that applying $N$ fertilizer with four splits during rice growth (basal : seedling: tillering: panicle = 5: $2: 2: 1$ ) results in significantly higher grain yield compared to application with three times (basal: tillering : panicle $=5: 4: 1$ ). Indirect-seeded rice, $\mathrm{N}$ application rates typically range from $150-300 \mathrm{~kg} / \mathrm{ha}$. The application rate of $\mathrm{N}$ also may vary with soil types (Machado Pereira et al., 2021). Hence research work was initiated at heavy textured Old Cauvery delta soil and light textured New Cauvery delta soil to study the nitrogen application rates on growth, yield and soil properties of rice.

\section{MATERIALS AND METHODS}

Field experiments were completed during 2019-20 and 2020-21at both the locations, i.e.Tamil Nadu Rice Research Institute of old Cauvery delta zone of heavy textured soil and Agriculture Research Station, Thanjavur of light-textured New Cauvery Delta soil. Totally four field experiments in each location and altogether, eight experiments were completed. Field experiments were conducted during kuruvai (June to September) and samba seasons (August to December) for the first year 2019-20. In the second year also, field experiments were conducted (2020-21) during kuruvai and samba seasons at both locations. The details of field experiments are presented below:

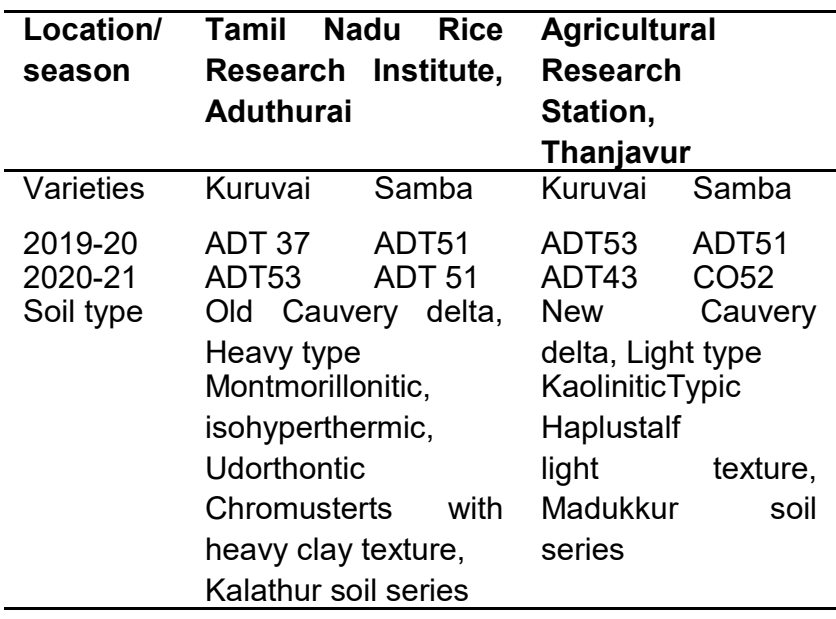

The treatments tried in all the locations and seasons were T1:No nitrogen (Control), T2: $50 \mathrm{~kg} \mathrm{~N} \mathrm{ha}^{-1}$., T3: 75 $\mathrm{kg} \mathrm{N} \mathrm{ha}^{-1}$., T4: $100 \mathrm{~kg} \mathrm{~N} \mathrm{ha}^{-1}$., T5: $125 \mathrm{~kg} \mathrm{~N} \mathrm{ha}^{-1}$ and T6: $150 \mathrm{~kg} \mathrm{~N}^{-1}$. $\mathrm{N}$ was applied in four splits at 30 (20\%), 60 (35\%), 90 (35\%) and 120 (10\%) DAS. Fertilizers of $100 \% \mathrm{P}_{2} \mathrm{O}_{5}, 25 \% \mathrm{~K}_{2} \mathrm{O}$ and $100 \% \mathrm{ZnSO}_{4}$ were applied as basally. ${ }^{\text {st }}, \mathrm{II}^{\text {nd }}$ and $\mathrm{III}^{\text {rd }}$ top dressing of $\mathrm{N} \& \mathrm{~K}$ fertilizers were applied as per the treatment schedule on 30,60 and 90 DAS for kuruvai and for samba season, $\mathrm{N}$ was applied as $20 \%$ (20-25DAS), $35 \%$ (40-45DAS),35\% (60-65DAS) and $10 \%$ (90DAS). The soil samples were collected from the field experiment at $0-15 \mathrm{~cm}$ depth during kuruvai and summer seasons. All the samples were brought to the laboratory and air-dried and passed through a $2 \mathrm{~mm}$ sieve was used for determining other soil analysis. The methods employed for analysing soil parameters based on standard procedures viz. Organic carbon by chromic acid wet digestion(Walkley and Black (1934)), available Nitrogen by alkaline permanganate method (Asija (1956), available phosphorus by $0.5 \mathrm{M} \mathrm{NaHCO}_{3}$ (Olsen,1954), available potassium by Neutral Normal ammonium acetate method (Stanford and English, 1949).

\section{RESULTS AND DISCUSSION}

\section{Effect of nitrogen application on growth and yield attributes of rice}

In the old Cauvery delta zone (CDZ), field experiments were conducted to study the effect of graded doses of nitrogen during 2019-20 in kuruvai season and results showed that the higher number of productive tillers $\left(329 / \mathrm{m}^{2}\right)$ was recorded in the T6 which was on par with T5 $\left(318 \mathrm{nos} / \mathrm{m}^{2}\right)$ (Table1). The plant height also recorded a higher value in the T6 $(105.8 \mathrm{~cm})$ which was at par with $T 5(104.6 \mathrm{~cm})$. The highest grain yield was obtained in the treatment T6 -application of $150 \mathrm{~kg} \mathrm{Nha}^{-1}$ 
(5596kg/ha) which was statistically on par with treatment T5 $-125 \mathrm{~kg} \mathrm{~N} / \mathrm{ha}(5326 \mathrm{~kg} / \mathrm{ha})$. So increasing the dose of nitrogen application did not influence yield significantly. The results pertaining to the field experiment conducted in the old CDZ samba season 2020 are given in Table 2. The higher grain yield $(5636 \mathrm{~kg} / \mathrm{ha})$ was recorded in T6, which was statistically on par with T5 (5494 kg/ha). The number of productive tillers $/ \mathrm{m}^{2}$ of 411 was recorded T6, which was statistically on par with T5 $\left(399\right.$ numbers $\left./ \mathrm{m}^{2}\right)$. The results of the second year trial conducted during 2020-21 also confirmed the first year experimental results and are depicted in Fig.1.The season results clearly indicated that the direct-seeded rice in the old Cauvery delta zone responded statistically up to $125 \mathrm{~kg} \mathrm{~N} / \mathrm{ha}$. So increasing the dose of nitrogen application did not influence yield significantly.

In the New Cauvery delta zone, field experiments were conducted during kuruvai and samba seasons of 201920 and 2020-21 and results of kuruvai 2019-20 indicated that higher grain yield was recorded in the T6 (5140 $\mathrm{kg} / \mathrm{ha})$, which was statistically on par with $T 5(4550 \mathrm{~kg} /$ ha). Numbers of productive tillers and grain yield were significantly higher in T6 $\left(345 / \mathrm{m}^{2}\right)$ followed by T5(291/ $\mathrm{m}^{2}$ ) \& $T 4\left(235 / \mathrm{m}^{2}\right)$. During samba 2020 (Table 7 ), the results revealed that T6 recorded a higher grain yield of $4450 \mathrm{~kg} / \mathrm{ha}$, which was on par with T5 $(4270 \mathrm{~kg} / \mathrm{ha})$. The analysed data revealed that significantly higher plant height $1106.1 \mathrm{~cm}$ ) and No. of productive tillers $\left(402 / \mathrm{m}^{2}\right)$ were recorded in T6, which was on par with T5. In the confirmation trial (fig2), The statistical analysis of the data revealed that significantly higher plant height $(109.8 \mathrm{~cm}$ and $107.3 \mathrm{~cm})$, No. of productive tillers $\left(338 \& 304 / \mathrm{m}^{2}\right)$ and grain yield $\left(5017 \& 4760 \mathrm{~kg} \mathrm{ha}{ }^{-}\right.$ $\left.{ }^{1}\right)$ were recorded in T6 and T5 respectively but on par with each other followed by T4, T3 \& T2. Significantly least yield and yield parameters were recorded in $\mathrm{T} 1$. From all four experiments, the application of $\mathrm{N}$ significantly promoted the yield attributes of rice as compared to control. The yield attributing characters such as productive tillers $/ \mathrm{m} 2$ and the number of filled grains were maximum at $150 \mathrm{kgN} / \mathrm{ha}$ and on par with $125 \mathrm{~kg} /$ ha.Direct seeded rice produced more tillers under favourable growing conditions. The reason might be

Table 1. Effect of nitrogen application on growth and yield attributes of rice in old Cauvery delta zone (2019-20)

\begin{tabular}{|c|c|c|c|c|c|c|}
\hline \multirow[b]{2}{*}{ Treatments } & \multicolumn{3}{|c|}{ Kuruvai } & \multicolumn{3}{|c|}{ Samba } \\
\hline & $\begin{array}{l}\text { Plant height } \\
\text { (cm) }\end{array}$ & $\begin{array}{l}\text { No. of produc- } \\
\text { tive tillers } / \mathrm{m}^{2}\end{array}$ & $\begin{array}{l}\text { Grain Yield } \\
\text { (kg/ha) }\end{array}$ & $\begin{array}{l}\text { Plant height } \\
\text { (cm) }\end{array}$ & $\begin{array}{l}\text { No. of produc- } \\
\text { tive tillers } / \mathrm{m}^{2}\end{array}$ & $\begin{array}{l}\text { Grain Yield } \\
\text { (kg/ha) }\end{array}$ \\
\hline T1 : Control & 87.5 & 185 & 3438 & 85.6 & 175 & 4026 \\
\hline $\mathrm{T} 2: 50 \mathrm{~kg} \mathrm{~N} \mathrm{ha}{ }^{-1}$ & 93.3 & 242 & 4325 & 92.4 & 229 & 4485 \\
\hline T3 : $75 \mathrm{~kg} \mathrm{~N} \mathrm{ha}^{-1}$ & 95.8 & 247 & 4582 & 101.5 & 282 & 4853 \\
\hline T4 : $100 \mathrm{~kg} \mathrm{~N} \mathrm{ha}^{-1}$ & 98.2 & 252 & 4896 & 108.2 & 336 & 5175 \\
\hline T5 : $125 \mathrm{~kg} \mathrm{~N} \mathrm{ha}^{-1}$ & 104.6 & 318 & 5326 & 112.7 & 399 & 5494 \\
\hline T6 : 150 kg N ha-1 & 105.8 & 329 & 5596 & 115.8 & 411 & 5636 \\
\hline SEd & 3.4 & 15 & 142 & 1.6 & 18.7 & 148 \\
\hline$C D(p=0.05)$ & 6.7 & 32 & 353 & 3.6 & 35.3 & 316 \\
\hline
\end{tabular}

Table 2. Effect of nitrogen application on growth and yield attributes $(\mathrm{kg} / \mathrm{ha})$ of rice in new Cauvery delta zone (2019-20)

\begin{tabular}{|c|c|c|c|c|c|c|}
\hline \multirow[b]{2}{*}{ Treatments } & \multicolumn{3}{|c|}{ Kuruvai } & \multicolumn{3}{|c|}{ Samba } \\
\hline & $\begin{array}{l}\text { Plant height } \\
\text { (cm) }\end{array}$ & $\begin{array}{l}\text { No. of produc- } \\
\text { tive tillers } / \mathrm{m}^{2}\end{array}$ & $\begin{array}{l}\text { Grain Yield } \\
\text { (kg/ha) }\end{array}$ & $\begin{array}{l}\text { Plant height } \\
\text { (cm) }\end{array}$ & $\begin{array}{l}\text { No. of produc- } \\
\text { tive tillers } / \mathrm{m}^{2}\end{array}$ & $\begin{array}{l}\text { Grain Yield } \\
\text { (kg/ha) }\end{array}$ \\
\hline T1 : Control & 84.4 & 170 & 2920 & 75.3 & 165 & 2960 \\
\hline T2 : $50 \mathrm{~kg} \mathrm{~N} \mathrm{ha}^{-1}$ & 87.5 & 227 & 3710 & 87.4 & 220 & 3270 \\
\hline T3 : $75 \mathrm{~kg} \mathrm{~N} \mathrm{ha-1}$ & 90.5 & 231 & 3750 & 92.1 & 271 & 3610 \\
\hline T4 : 100 kg N ha ${ }^{-1}$ & 95.6 & 235 & 4430 & 98.5 & 327 & 3930 \\
\hline T5 : $125 \mathrm{~kg} \mathrm{~N} \mathrm{ha}^{-1}$ & 99.3 & 291 & 4550 & 103.4 & 389 & 4270 \\
\hline T6 : $150 \mathrm{~kg} \mathrm{~N} \mathrm{ha-1}$ & 97.8 & 345 & 5140 & 106.1 & 402 & 4450 \\
\hline SEd & 1.3 & 24 & 294 & 1.1 & 23 & 141 \\
\hline$C D(p=0.05)$ & 3.5 & 54 & 578 & 2.4 & 49 & 290 \\
\hline
\end{tabular}


due to higher plant density and absence of transplanting shock (Schnier et al., 1990).Ali etal. (2006) reported that panicles per square meter were higher under DSR in clay soil. Sathya (2007) reported that the rice grain yield was maximum at $175 \mathrm{~kg} / \mathrm{ha}$ and was at par with $150 \mathrm{~kg} / \mathrm{ha}$. Singh et al. (2015) obtained responses up to $120 \mathrm{~kg} / \mathrm{ha}$ where applied $\mathrm{N}$ fertilizer increased grain yield of direct-seeded rice by $62 \%$. Beyond $120 \mathrm{~kg} / \mathrm{ha}$, no increase in grain yield was observed, but its application resulted in more production of rice straw. Ramesh et al. (2009) recorded a significantly higher number of tillers $/ \mathrm{m}^{2}$ with the nitrogen application of $150 \mathrm{~kg} / \mathrm{ha}$, which was on par with the results of $125 \mathrm{~kg} / \mathrm{ha}$ of Pathak et al. (2011) reported higher grain yield of dry direct-seeded rice at NPK dose of $120-150 \mathrm{~kg} \mathrm{~N} .60 \mathrm{~kg}$ $\mathrm{P}_{2} \mathrm{O}_{5}$ and $40 \mathrm{~kg} \mathrm{~K}_{2} \mathrm{O} / \mathrm{ha}$ along with $25 \mathrm{~kg} \mathrm{ZnSO}_{4} / \mathrm{ha}$. The increase in the $\mathrm{N}$ level resulted in a reduction in the use efficiency of nitrogen. This might be due to the greater loss of nitrogen at higher doses. This is in line with Thind et al. (2018) that was in a rice crop with 130 $\mathrm{kg} \mathrm{N} / \mathrm{h}$. Seema et al.(2014) reported that $125 \mathrm{~kg} / \mathrm{ha}$ of $\mathrm{N}$ caused a significant increase in dry matter production due to higher $\mathrm{N}$ availability. Liu et al. (2015) reported that DSR recorded comparable grain yield and nutrient use efficiency. The results obtained in the present ex-

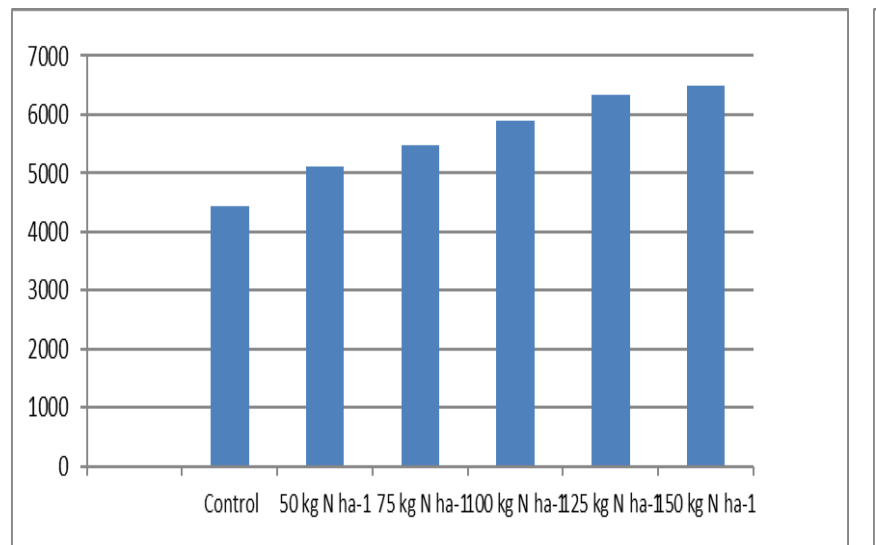

Fig. 1. Effect of nitrogen application on grain yield of rice in old Cauvery delta zone -confirmation trial 2020-21

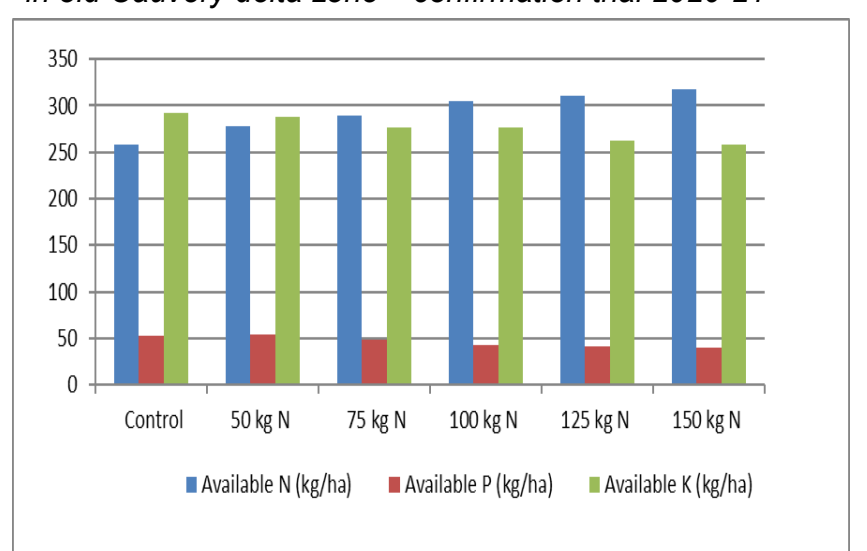

Fig. 3. Effect of nitrogen application on soil properties of rice in old Cauvery delta zone-confirmation trial 2020-21 periment of increasing yield with increasing $\mathrm{N}$ application is in line with reports of direct-seeded rice, which was reported by Nayak et al. (2015); Reddy et al. (2017); Munda et al. (2017) and Ramya et al. (2019)in rice crop.

\section{Effect of graded levels of $\mathbf{N}$ fertiliser on Soil available nutrients}

In the old Cauvery delta soil, regarding post-harvest soil characteristics of 2019-20 experiments of kuruvai and samba showed that increasing dose of nitrogen levels increased the nitrogen content in soil significantly. The higher available nitrogen content of $312 \mathrm{~kg} /$ ha,292 kg/ha was recorded for $\mathrm{N}$ application @ 150kg/ ha in the kuruvai and samba seasons(Table 3 ). The result was statistically on par with $\mathrm{N}$ application of $125 \mathrm{~kg} / \mathrm{ha}$ of $309 \mathrm{~kg} / \mathrm{ha}$ and $289 \mathrm{~kg} / \mathrm{ha}$, respectively, in the kuruvai and samba seasons. But the effect of nitrogen treatments on available $P$ and $Z n$ was not significant. Further, the availability of $\mathrm{K}$ decreases with increasing doses of nitrogen might be due to increased uptake of these nutrients. The same trend of results was obtained during the second year also. The soil available nutrient status in the confirmation trial also followed the same trend (Fig. 3)

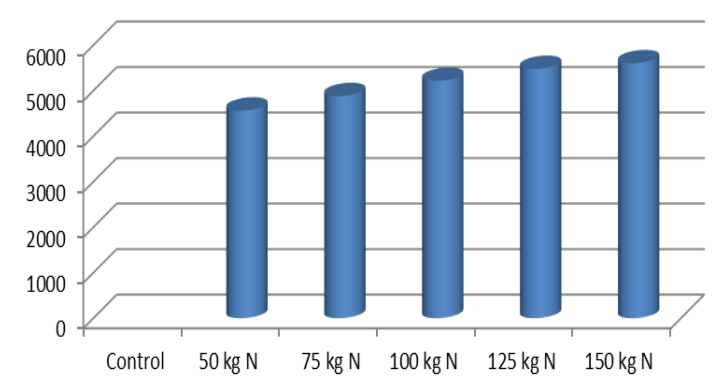

Fig. 2. Effect of nitrogen application on grain yield of rice in new Cauvery delta zone -confirmation trial 2020-21

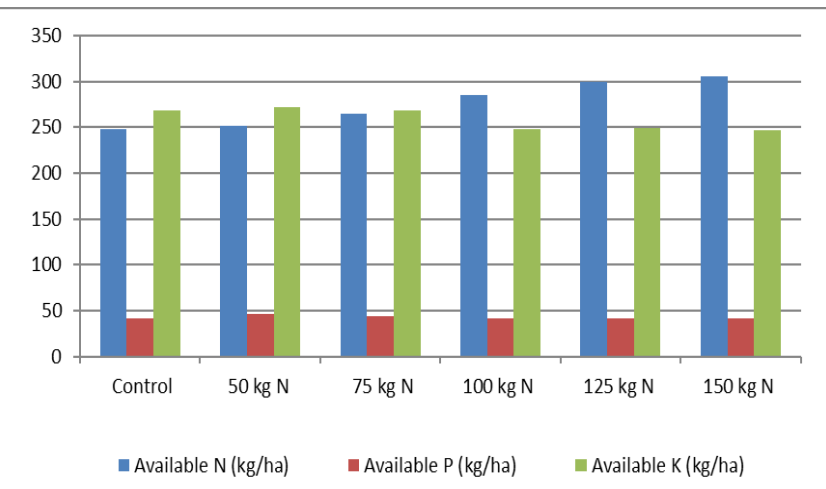

Fig. 4. Effect of nitrogen application on soil properties of rice in new Cauvery delta zone -confirmation trial 2020-21 
In the new CDZ, during kuruvai the results revealed the higher available $N(267 \mathrm{~kg} / \mathrm{ha})$, available $\mathrm{P}(19 \mathrm{~kg} / \mathrm{ha})$ and available $\mathrm{K}(241 \mathrm{~kg} / \mathrm{ha})$ in $\mathrm{T} 6$ followed by $\mathrm{T} 5$. During samba also the T6 was recorded a higher value of $259 \mathrm{~kg} / \mathrm{ha}$, which is on par with T5 $(237 \mathrm{~kg} / \mathrm{ha})$. With respect to available $\mathrm{K}$, a higher value was recorded in the T6 $(215 \mathrm{~kg} / \mathrm{ha})$, which was on par with T5 $(213 \mathrm{~kg} /$ ha). In the confirmation trial also the nitrogen application followed the same trend(Fig. 4). Johnkutty et al. (2000) reported that higher nitrogen application would increase the $P$ availability in rice. Linwattana (2001) reported that yield and agronomic parameters of directseeded rice gave a better response to $\mathrm{N}$ application. Sudhakar et al. (2003) reported an increase in soil available NPK from 0 to $120 \mathrm{~kg} \mathrm{~N} / \mathrm{ha}$ in Coimbatore.

\section{Effect of graded levels of $\mathbf{N}$ fertiliser on pooled} mean nutrient uptake of grain

The effect of $\mathrm{N}$ application on nutrient uptake of rice grain for pooled data of all the seasons for both the locations showed that the uptake was increased with increasing levels. N application @ $150 \mathrm{~kg} / \mathrm{ha}$ recorded higher nitrogen nutrient uptake in grain $(81.2 \mathrm{~kg} / \mathrm{ha})$ (table5)which was on par with T5 $(75.9 \mathrm{~kg} / \mathrm{ha})$ and T4 $(73.1 \mathrm{~kg} / \mathrm{ha})$. Regarding P uptake, except for control, all Nitrogen application treatments recorded comparable values ranging from $9.23 \mathrm{~kg} / \mathrm{ha}$ to $11.39 \mathrm{~kg} / \mathrm{ha}$. The higher potassium uptake was recorded in the T6 (51.3 $\mathrm{kg} / \mathrm{ha})$, which was on par with T5 (46.1 kg/ha), T4 (45.9 $\mathrm{kg} / \mathrm{ha}$ ). The uptake of nutrients by straw also followed the same trend of result: N application @ 150 kg/ha recorded a higher value, which was on par with $\mathrm{N}$ @125 kg/ha. Raj et al. (2017) reported that higher N levels improved the vegetative foraging capacity of the roots, which in turn increased the NPK uptake in rice crops.. Increasing $\mathrm{N}$ application stimulated more vegetative growth and increased the foraging capacity of roots, which increased the uptake of phosphorus. Rammohanet al. (1999) observed the highest $\mathrm{P}$ and $\mathrm{K}$ uptake with the application of $150 \mathrm{~kg} / \mathrm{ha}$. Increasing dose of $\mathrm{N}$ increasing the $\mathrm{N}$ uptake was reported by Marlar et al. (2007). Sathya et al. (2007) reported that agronomic and physiological efficiency was maximum at $150 \mathrm{~kg} \mathrm{~N} /$ ha. Singh et al. (2015) reported that increasing $\mathrm{N}$ application stimulated more vegetative growth and increased the foraging capacity of roots, which

Table 3. Effect of nitrogen application on soil available nutrients of rice in old Cauvery delta zone (2019-20)

\begin{tabular}{|c|c|c|c|c|c|c|c|c|}
\hline \multirow[b]{2}{*}{ Treatments } & \multicolumn{4}{|c|}{ Kuruvai } & \multicolumn{4}{|c|}{ Samba } \\
\hline & $\begin{array}{l}\mathrm{N} \\
\text { (kg/ha) }\end{array}$ & $\begin{array}{l}P \\
\text { (kg/ha) }\end{array}$ & $\begin{array}{l}\mathrm{K} \\
\text { (kg/ha) }\end{array}$ & $\begin{array}{l}\mathrm{Zn} \\
(\mathrm{ppm})\end{array}$ & $\begin{array}{l}\mathrm{N} \\
\text { (kg/ha) }\end{array}$ & $\begin{array}{l}P \\
\text { (kg/ha) }\end{array}$ & $\begin{array}{l}\mathrm{K} \\
\text { (kg/ha) }\end{array}$ & $\begin{array}{l}\mathrm{Zn} \\
\text { (ppm) }\end{array}$ \\
\hline T1 : Control & 252 & 62.5 & 282 & 0.98 & 232 & 58.2 & 282 & 0.88 \\
\hline T2 : $50 \mathrm{~kg} \mathrm{~N} \mathrm{ha}^{-1}$ & 272 & 64.2 & 278 & 0.95 & 244 & 56.5 & 278 & 0.86 \\
\hline T3 : $75 \mathrm{~kg} \mathrm{~N} \mathrm{ha}^{-1}$ & 283 & 57.6 & 267 & 0.92 & 253 & 54.6 & 274 & 0.84 \\
\hline T4 : $100 \mathrm{~kg} \mathrm{~N} \mathrm{ha}^{-1}$ & 293 & 52.7 & 257 & 0.87 & 273 & 52.4 & 262 & 0.80 \\
\hline T5 : $125 \mathrm{~kg} \mathrm{~N} \mathrm{ha}^{-1}$ & 309 & 50.6 & 252 & 0.82 & 289 & 50.5 & 252 & 0.80 \\
\hline T6 : $150 \mathrm{~kg} \mathrm{~N} \mathrm{ha}^{-1}$ & 312 & 50.4 & 248 & 0.75 & 292 & 50.1 & 245 & 0.80 \\
\hline SEd & 11 & 08 & 11 & 0.12 & 13 & 07 & 12 & 0.12 \\
\hline$C D(p=0.05)$ & 22 & NS & 19 & NS & 24 & NS & 21 & NS \\
\hline
\end{tabular}

Table 4. Effect of nitrogen application on soil available nutrients of rice in new Cauvery delta zone (2019-20)

\begin{tabular}{|c|c|c|c|c|c|c|c|c|}
\hline \multirow[b]{2}{*}{ Treatments } & \multicolumn{4}{|c|}{ Kuruvai } & \multicolumn{4}{|c|}{ Samba } \\
\hline & $\begin{array}{l}N \\
\text { (kg/ha) }\end{array}$ & $\begin{array}{l}P \\
\text { (kg/ha) }\end{array}$ & $\begin{array}{l}\text { K } \\
\text { (kg/ha) }\end{array}$ & $\begin{array}{l}\mathrm{Zn} \\
\text { (ppm) }\end{array}$ & $\begin{array}{l}N \\
\text { (kg/ha) }\end{array}$ & $\begin{array}{l}P \\
\text { (kg/ha) }\end{array}$ & $\begin{array}{l}\text { K } \\
\text { (kg/ha) }\end{array}$ & $\begin{array}{l}Z \mathrm{Zn} \\
\text { (ppm) }\end{array}$ \\
\hline T1 : Control & 190 & 13 & 196 & 0.33 & 189 & 18 & 192 & 0.43 \\
\hline T2 : $50 \mathrm{~kg} \mathrm{~N} \mathrm{ha}^{-1}$ & 226 & 15 & 198 & 0.37 & 225 & 19 & 199 & 0.45 \\
\hline T3 : 75 kg N ha-1 & 248 & 14 & 205 & 0.43 & 246 & 18 & 201 & 0.45 \\
\hline T4 : $100 \mathrm{~kg} \mathrm{~N} \mathrm{ha}^{-1}$ & 236 & 15 & 209 & 0.45 & 235 & 19 & 205 & 0.49 \\
\hline T5 : $125 \mathrm{~kg} \mathrm{~N} \mathrm{ha}^{-1}$ & 247 & 17 & 221 & 0.47 & 237 & 20 & 213 & 0.48 \\
\hline T6 : $150 \mathrm{~kg} \mathrm{~N} \mathrm{ha}^{-1}$ & 258 & 19 & 235 & 0.45 & 259 & 20 & 215 & 0.49 \\
\hline SEd & 09 & 07 & 12 & 0.12 & 12 & 1.1 & 8 & NS \\
\hline$C D(p=0.05)$ & 18 & NS & 19 & NS & 27 & NS & 14 & NS \\
\hline
\end{tabular}


Bama, K. S. et al. / J. Appl. \& Nat. Sci. 13(4), 1462 - 1469 (2021)

Table 5. Effect of nitrogen application on nutrient uptake $(\mathrm{kg} / \mathrm{ha})$ of rice in old Cauvery delta zone (2019-20)

\begin{tabular}{lcccccc}
\hline Treatments & \multicolumn{3}{c}{ Grain } & \multicolumn{3}{c}{ Straw } \\
\cline { 2 - 6 } & Nitrogen & Phosphorus & Potassium & Nitrogen & Phosphorus & Potassium \\
\hline T1: Control & 50.5 & 6.66 & 34.6 & 30.2 & 7.10 & 55.0 \\
T2 : $50 \mathrm{~kg} \mathrm{~N} \mathrm{ha}^{-1}$ & 60.4 & 9.23 & 38.4 & 33.3 & 8.20 & 65.6 \\
T3 : $75 \mathrm{~kg} \mathrm{~N} \mathrm{ha}^{-1}$ & 66.3 & 9.32 & 41.6 & 36.2 & 9.32 & 69.1 \\
T4 : $100 \mathrm{~kg} \mathrm{~N} \mathrm{ha}^{-1}$ & 73.1 & 9.43 & 45.9 & 40.1 & 10.61 & 75.5 \\
T5 : $125 \mathrm{~kg} \mathrm{~N} \mathrm{ha}^{-1}$ & 75.9 & 10.39 & 46.1 & 39.9 & 12.02 & 81.0 \\
T6 : $150 \mathrm{~kg} \mathrm{~N} \mathrm{ha}^{-1}$ & 81.2 & 11.39 & 51.3 & 51.3 & 9.09 & 81.2 \\
Sed & 9.8 & 1.5 & 5.8 & 4.5 & 2.1 & 8.2 \\
CD $(p=0.05)$ & 18.2 & 3.2 & 11.5 & 9.6 & 4.1 & 16.5
\end{tabular}

Table 6. Application of $\mathrm{N}$ for direct seeded rice for old and new Cauvery delta zone :125 kg N/ha

\begin{tabular}{|c|c|c|c|c|c|c|c|c|c|c|}
\hline Treatments & $\begin{array}{l}\text { Kuruvai } \\
2019\end{array}$ & $\begin{array}{l}\text { Kuruvai } \\
2020\end{array}$ & $\begin{array}{l}\text { Pooled } \\
\text { mean }\end{array}$ & NUE & BCR & $\begin{array}{l}\text { Samba } \\
2019-20\end{array}$ & $\begin{array}{l}\text { Samba } \\
2020-21\end{array}$ & $\begin{array}{l}\text { Pooled } \\
\text { mean }\end{array}$ & NUE & BCR \\
\hline \multicolumn{11}{|c|}{ Old delta-TRRI,Aduthurai,Clay,Kalathur soil series } \\
\hline $125 \mathrm{~kg} \mathrm{~N} \mathrm{ha}^{-1}$ & 5326 & 6326 & 5826 & 15.10 & 1.62 & 5494 & 5477 & 5485 & 11.36 & 1.47 \\
\hline 150 kg N ha-1 & 5596 & 6496 & 6046 & 14.05 & 1.56 & 5636 & 5601 & 5618 & 10.35 & 1.38 \\
\hline SED & 142 & 258 & 168 & & & 148 & 150 & 152 & & \\
\hline$C D(p=0.05)$ & 353 & 421 & 325 & & & 316 & 311 & 315 & & \\
\hline \multicolumn{11}{|c|}{ New delta -ARS, Thanjavur, Sandy loam, madukkur soil series } \\
\hline 125 kg N ha-1 & 4550 & 4760 & 4655 & 13.10 & 1.22 & 4270 & 4862 & 4566 & 13.06 & 1.17 \\
\hline 150 kg N ha-1 & 5140 & 5047 & 5094 & 13.80 & 1.21 & 4450 & 4782 & 4616 & 13.81 & 1.01 \\
\hline SED & 294 & 318 & 215 & & & 141 & 153 & 115 & & \\
\hline$C D(p=0.05)$ & 578 & 626 & 465 & & & 290 & 307 & 245 & & \\
\hline
\end{tabular}

increased the uptake of potassium by rice. Thind et al. (2017) reported that nitrogen uptake in grain increased with increasing $\mathrm{N}$ rate from 120 to $150 \mathrm{~kg} / \mathrm{ha}$.

\section{Effect of graded levels of $\mathbf{N}$ fertiliser on the economics of rice}

The field experiment conducted on nitrogen application on direct-seeded rice revealed that the $\mathrm{BC}$ ratio was higher under $\mathrm{N}$ applied @125 kg/ha of 1.62 and 1.47 respectively for old and new Cauvery delta zone. Ye et al. (2007) reported that the nitrogen use efficiency under conventional transplanted rice (30-40\%) was lesser as compared to direct-seeded rice. Ali et al. (2006) reported that the highest benefit-cost ratio of 2.36 was obtained from the dry seeding method followed by the drum seeding. Direct seeded rice required less cost to cultivate as compared to transplanted rice. Higher net return per hectare and $\mathrm{B}$ : $\mathrm{C}$ ratio was observed under dry direct-seeded rice (2.00) compared with puddled transplanted rice (1.63). The reason might be due to less labour and low irrigation requirement, which contributed to the low cost of cultivation. Moreover, higher farm gate prices of paddy as earlier harvest are the major reasons for this profitability. Singh et al. (2015) reported that the maximum $\mathrm{BC}$ ratio of 1.59 was ob- tained from the application of $150 \mathrm{kgN} / \mathrm{ha}$ (1.59) followed by $120 \mathrm{kgN} / \mathrm{ha}$ (1.54). Younas et al. (2021) reported that the total cost of production, net economic benefits per hectare and BCR for direct-seeded rice were Rs. 112047 Rs15014 and 1.11. Kaur and Singh. (2017) reported that, B: C ratio of direct-seeded rice varied from 2.29 to 3.12. Ramya and Pandove (2021) reported that the grass return, net return and $B C$ ratio were higher in the $\mathrm{N}$ application of $150 \mathrm{~kg} / \mathrm{ha}$ followed by $125 \mathrm{~kg} / \mathrm{ha}$.

\section{Conclusion}

For direct-seeded rice, based on the grain yield and soil available nutrients status, for both in Old and new Cauvery delta zone of Tamil Nadu, Nitrogen application @ $150 \mathrm{~kg} \mathrm{ha}^{-1}$ and @125 kg ha ${ }^{-1}$ during kuruvai and samba seasons showed comparable grain yield. Based on economics, $\mathrm{N}$ applied @125 kg/ha recorded a higher $\mathrm{BC}$ ratio for direct-seeded rice in the old and new Cauvery delta zone. For the benefit of farmers of both deltaic regions, the nitrogen application of $125 \mathrm{~kg} \mathrm{ha}^{-1}$ for direct-seeded rice is recommended in place of the already recommended dose of $150 \mathrm{~kg} / \mathrm{ha}$ in the crop production guide of Tamil Nadu. The results could save 
Bama, K. S. et al. / J. Appl. \& Nat. Sci. 13(4), 1462 - 1469 (2021)

money by reducing the nitrogen dose without affecting economics and preventing the environment from reducing nitrogen use.

\section{Conflict of interest}

The authors declare that they have no conflict of interest.

\section{REFERENCES}

1. Alam, S. M. S., Khatun,M., Islam, M.S. \& Chakma,A.S. (2021).Role of Chemical fertilizers (NPKSZn) and missing of major nutrients (NPK) on rice yield. World Scientific News., 162,133-147.

2. Ali, M. A., Latha, J. K., Rickman, J. \& Lales, J. S. (2006). Comparison of different methods of rice establishment and nitrogen management strategies for low land rice. $J$. Crop Imp.,16,173-189.https://doi.org/10.1300/J411v16n 0 1_12

3. Choudhury, A. \& Kennedy, I.(2005). Nitrogen fertilizer losses from rice soils and control of environmental pollution problems.Communications in Soil science and Plant analysis., $\quad 36,1625-1639 . h t t p s: / / d o i . o r g / 10.1081 / C S S-$ 200059104

4. De Datta, S. (1995). Nitrogen transformations in wetland rice ecosystems. Fertilizer Research.,42 (1),193-203.

5. Gopal, R., Jat, R., Malik, R., Kumar, V., Alam, M., Mazid, M., Saharawat,Y., McDonald,A.\& Gupta,R.(2019). Direct dry seeded rice production technology and weed management in rice based systems.Gates Open Res.,3 207.https://doi.org/10.21955/gatesopenres.1115021.1

6. Johnkutty, L., Kandaswamy, O. S. \& Palanippan, S.P. (2000). Time course leaf $N$ concentration in rice under different nitrogen application strategies and development of simulation models. J. Trop. Agric., 37, 40-45.

7. Kaur, J. \& Singh, A. (2017). Direct Seeded Rice: Prospects, Problems / Constraints and Researchable issues India. Curr. Agri. Res., 5(1), 13-32.http:// dx.doi.org/10.12944/CARJ.5.1.03

8. Ladha, J. K., Pathak, H., Krupnik,T. J., Six,J. \& Van Kessel, C. (2005). Efficiency of fertilizer nitrogen in cereal production: retrospects and prospects. Advances in Agronomy., 87, 85-156.https://doi.org/10.1016/S00652113(05)87003-8

9. Linwattana, G. (2001). Nitrogen Management for direct seeded rice (Oryza sativa L.) in drought-prone lowlands of Ubon Ratchathani, Thailand. Ph. D Thesis, University of the Philippines Los Banos, Philippines.

10. Liu, H., Hussain, S., Zheng, M., Peng, S., Huang, J., Cui, K. \& Nie, L. (2015). Dry direct- seeded rice as an alternative to transplanted-flooded rice in Central China. Agron. Sustain. . Dev., 35, 285-294.10.1007/s13593-014-0239-0

11. Machado,P.A.,Schmiele, M., Souza, E. J., Ávila, B., Ramos, A., Zavareze,E. \& Gularte.M.(2021). Extrudate gluten-free breakfast cereals from rice and corn flours with different amylose content: technological and sensory properties. International journal of food science \& technology., 56 (8),4182-4190.https://doi.org/10.1111/ijfs. 15048

12. Marlar, N.O., Shivay, Y. S. \& Kumar, D. (2007). Effect of nitrogen and sulphur fertilization on yield attributes, productivity and nutrient uptake of aromatic rice (Oryza sativa). Indian J. Agric. Sci., 77(11), 772-775.

13. Mondal, S., Kumar, S., Haris, A.A., Dwivedi, S.K., Bhatt, B. P. \& Mishra, J. S. (2016).Effect of different rice establishment methods on soil physical properties in droughtprone, rainfed lowlands of Bihar. India. Soil Res., 54, 997 - 1006. https://doi.org/10.1071/SR15346

14. Munda, S., Saha, S., Adak, T. \& Jambhulkar, N. (2017). Weed Management in aerobic rice: Role of establishment methods and herbicides. Expl. Agric.,1-17.https:// doi.org/10.1017/S0014479717000576

15. Nayak, B. R., Pramanik, K., Panigrahy, N., Dash, A. K. \& Swain, S. K. (2015). Yield, nitrogen uptake and nitrogen use efficiency indices of aerobic rice (Oryza sativa L.) under various irrigation regimes and nitrogen levels. Int. J. Bio-res. Env. Agril. Sci., 1(2), 8-13.

16. Pathak, H., Tewari, A. N., Sankhyan, S., Dubey, D. S., Mina, U., Virendar, K., Jain, N. \& Bhatia, A. (2011). Direct seeded rice-Potential, performance and problems - A Review. Curr. Adv. Agric. Sci., 3(2), 77-88.

17. Olsen, S. R. (1954). Estimation of available phosphorus in soils by extraction with sodium bicarbonate: United States Department Of Agriculture,Washington.

18. Qi, X., Wu,W., Shah,F., Peng,S., Huang,J., Cui,K., Liu,H.\& Nie.L.(2012). Ammonia volatilization from ureaapplication influenced germination and early seedling growth of dry direct-seeded rice. The Scientific World Journal., 20, 1-2.https://doi.org/10.1100/2012/857472

19. Ramya, M., Nideep, T., Nampoori, V. \& Kailasnath, M (2019). Understanding the role of alcohols in the growth behaviour of $\mathrm{ZnO}$ nanostructures prepared by solution based synthesis and their application in solar cells. New Journal of Chemistry., 43 (46),17980-17990.https:// doi.org/10.1039/C9NJ03212F

20. Ramya, S. \& Pandove, G. (2021). Integrated nutrient management in cowpea with the application of microbial inoculants. Legume Research: An International Journal., 44 (3).

21. Raj, S.K. \& Syriac, E. K. (2017). Nutrient availability and nutrient uptake as influenced by the post emergence application of herbicide mixtures. J. Trop. Agric., 55(2), 152160.

22. Ramesh, T., Sathiya, K., Padmanabhan, P. K. \& Martin, G. J. (2009). Optimization of nitrogen and suitable weed management practices for aerobic rice. Madr. Agric. J., 96, 344-348.

23. Rammohan, J., Chandrasekaran, B., Poonguzhalan, R., Mohan, R. \& Subramaniyan, M. (1999). Nutrient uptake as influenced by $\mathrm{N}$ levels in rice based cropping system. Vistas of rice Res. (Subramaniyan, M.Ed.), TRRI, Aduthurai, Tamil Nadu India., 225-260.

24. Reddy, B. G. M., Guruprased, G. S., Paramesh, D., Mahantashivayogayya, K. \& Ibrahim, M. (2017). Nitrogen management for optimum productivity of dry direct seeded rice (Oryza sativa L.) Under medium deep black soils. $J$. Farm Sci., 30(2), 177-180.http://14.139.155.167/.../8643

25. Sathya, K. (2007). Optimization of nitrogen level and split dose in aerobic rice (Oryza sativa L.). M. Sc. (Ag.) Thesis, Department of Agronomy, Tamil Nadu Agric Univ, Coimbatore, India., 62-73.

26. Krishna, M. \& Devi, M. T. T. (2014). Effect of nitrogen and weed management on nutrient uptake by weeds under direct seeded aerobic rice. The Bioscam., 9(2), 535537.http://www.the bio scan.in/Journals_PDF... 
27. Singh, D. K., Pandey, P.C., Qureshi, A. \& Gupta, S. (2015). Nitrogen management strategies for direct seeded aerobic rice (Oryza sativa L.) grown in mollisols of Uttarakhand (India). Int. J. Applied Pure Sci. Agric., 1(7), 130-138.

28. Sudhakar, G., Solaimalai, A. \& Ravisanker, N. (2003). Influence of cultivars and levels of nitrogen on yield, nutrient uptake and residual nutrient status of soil in semi dry rice. Agric. Sci. Digest., 23(2), 88-91.

29. Schnier, H., Dingkuhn,M., Datta,S., Mengel,K. \& Faronilo,J. (1990). Nitrogen fertilization of direct seeded flooded vs. transplanted rice: I. Nitrogen uptake, photosynthesis, growth, and yield. Crop Science., 30(6), 12761284.https://doi.org/10.2135/cropsci1990.0011183X003 $000060024 \mathrm{x}$

30. Stanford, G. \& English.L.(1949). Use of the flame photometer in rapid soil tests for $\mathrm{K}$ and $\mathrm{Ca}$. Agronomy Journal., 41 (9), 446-447.https://doi.org/10.2134/agronj1949.0002 $1962004100090012 x$

31. Thind, H. S., Singh, Y., Sharma, S., Goyal, D., Singh, V. \& Singh, B. (2017). Optimal rate and schedule of nitrogen fertilizer application for enhanced yield and nitrogen use efficiency in dry-seeded rice in north-western India. Archives Agron. Soil Sci., 1-29.https://doi.org/10.1080/03650 340.2017.1340642

32. Thind, H.S., Singh, Y., Sharma, S., Goyal, D., Singh, V. \& Singh,B.(2018). Optimal rate and schedule of nitrogen fertilizer application for enhanced yield and nitrogen use efficiency in dry-seeded rice in north-western India. Archives of Agronomy and Soil Science., 64 (2),196-207.

33. Thuy, N.H., Shan,Y., Wang,K., Cai,Z. \& Buresh,R.J. (2008). Nitrogen Supply in Rice Based Cropping Systems as Affected by Crop Residue Management. Soil science society of America journal., 72 (2),514-523.https:// doi.org/10.2136/sssaj2006.0403

34. Vasanthakumar, J. (2017). Yield Gap and Constraints Limiting Rice Productivity in Cauvery Delta Zone of Tamil Nadu. Indian Journal of Natural Sciences., 8 (43),1-5.

35. Walkley, A. \& Black, I.A.(1934). An examination of the Degtjareff method for determining soil organic matter, and a proposed modification of the chromic acid titration method.Soil Science., 37 (1),29-38.

36. Xu, L., Zhan, X., Yu, T., Nie, L., Huang, J., Cui, K., Wang, F., Li, Y. \& Peng, S.(2018). Yield performance of directseeded, double-season rice using varieties with short growth durations in central China. Field Crops Research., 227,49-55.https://doi.org/10.1016/j.fcr.2018.08.002

37. Ye, Q., Zhang, H., Wei, H., Zhang, Y., Wang, B., Xia, K., Huo, Z., Dai, Q. \& Xu, K.(2007). Effects of nitrogen fertilizer on nitrogen use efficiency and yield of rice under different soil conditions. Frontiers of Agriculture in China., 1 (1),30-36.https://doi.org/10.1007/s11703-007-0005-z

38. Yoon, K.S., Cho, J.Y., Choi, J.K. \& Son, J.G. (2006). Water management and $\mathrm{N}, \mathrm{P}$ losses from paddy fields in south Korea. Journal of the American Water Resources Association., 42 (5),1205-1216.https://doi.org/10.1111/ j.1752-1688.2006.tb05295.x

39. Younas, A., Xiukang,W., Yousaf,Z., Fiaz,S., Riaz,A., Hussain,S. \& Huang, S. (2021). Physiological and biochemical changes induced by Qiangdi nano- 863 biological assistant growth apparatus during rice seed priming under temperature stress. Brazilian Journal of Biology., 83.https://doi.org/10.1590/1519-6984.245206

40. Yu, J., Broutin, J., Chen, Z.Q., Shi, X., Li, H., Chu, D. \& Huang, Q. (2015). Vegetation changeover across the Permian-Triassic Boundary in Southwest China: extinction, survival, recovery and palaeoclimate: a critical review. Earth-Science Reviews., 149, 203-224.https://doi.o rg/10.1016/j.earscirev.2015.04.005

41. YU., Jing, Y.,Yang, S.N., Sun, W.C., Jiang, L.N. \& Qiang,W.(2013). Effects of nitrogen application level on rice nutrient uptake and ammonia volatilization. Rice Science., 20 (2),139-147.https://doi.org/10.1016/S1672-6308(13) 60117-1

42. Zhu, Y.,Chen,H., Fan,J., Wang,Y., Li,Y., Chen,J., Fan,J.,Yang,S., Hu,L. \& Leung, H.(2000). Genetic diversity and disease control in rice. Nature., 406 (6797),718722.https://doi.org/10.1038/35021046. 